\title{
Association between the degree of physical impairment from leprosy and dependence in activities of daily living among the elderly in a health unit in the State of Minas Gerais
}

\author{
Alisson da Costa Silva ${ }^{[1]}$, Raquel Conceição Ferreira ${ }^{[2]}$, Maria Aparecida Alves Ferreira ${ }^{[1]}$ \\ and Marco Túlio de Freitas Ribeiro ${ }^{[1]}$
}

[1]. Casa de Saúde Santa Izabel, Fundação Hospitalar do Estado de Minas Gerais, Betim, MG. [2]. Departamento de Odontologia Social e Preventiva, Faculdade de Odontologia, Universidade Federal de Minas Gerais, Belo Horizonte, MG.

\begin{abstract}
Introduction: In addition to the common alterations and diseases inherent in the aging process, elderly persons with a history of leprosy are particularly vulnerable to dependence because of disease-related impairments. Objective: determine whether physical impairment from leprosy is associated with dependence among the elderly. Methods: An analytical cross-sectional study of elderly individuals with a history of leprosy and no signs of cognitive impairment was conducted using a database from a former leprosy colony-hospital. The patients were evaluated for dependence in the basic activities of daily living (BADL) and instrumental activities of daily living (IADL), respectively) and subjected to standard leprosy physical disability grading. Subsequently, descriptive and univariate analyses were conducted, the latter using Pearson's chi-squared test. Results: A total of 186 elderly persons were included in the study. Of these individuals, $53.8 \%$ were women, $49.5 \%$ were older than 75 years of age, $93 \%$ had four or less years of formal education, $24.2 \%$ lived in an institution for the long-term care of the elderly (ILTC), and $18.3 \%$ had lower limb amputations. Among those evaluated, 79.8\% had visible physical impairments from leprosy (grade 2), 83.3\% were independent in BADL, and 10.2\% were independent in IADL. There was a higher impairment grade among those patients who were IADL dependent $(\mathrm{p}=0.038)$. Conclusions: The leprosy physical impairment grade is associated with dependence for IADL, creating the need for greater social support and systematic monitoring by a multidisciplinary team. The results highlight the importance of early diagnosis and treatment of leprosy to prevent physical impairment and dependence in later years.
\end{abstract}

Keywords: Leprosy (Hansen’s disease). Elderly. Dependence.

\section{INTRODUCTION}

A subset of tropical diseases is referred to as neglected or affecting neglected populations ${ }^{1}$. Leprosy (also known as Hansen's disease in Brazil) is part of this group and can lead to physical impairment and dependence. Its history is also marked by the social stigma it causes. One such example is the mandatory isolation of leprosy patients in the 1930s for prophylactic purposes. Beginning in 1960, the Juscelino Kubitschek government began to transition from this isolationist model to decentralized outpatient care. However, this new model did not affect the residents of the leprosy colonies that

\footnotetext{
Address to: Alisson da Costa Silva. Casa de Saúde Santa Izabel/Fundação Hospitalar de Minas Gerais. R. Olavo Bilac 113, 32650-820 Betim, MG, Brasil. Phone: 5531 3259-3319

e-mail: alisson_fisio@yahoo.com.br

Received 22 January 2014

Accepted 11 April 2014
}

were formed during the isolationist period because they did not acquire the right to leave until the 1980s.

In Brazil, there were at least 36 known leprosy colonies/ hospitals, most of which held individuals with severe physical sequelae from leprosy. The subsequent reintegration of these residents into society was extremely complex. Even after the end of compulsory isolation, many individuals chose to remain in the colonies in a metamorphosed form of isolation to avoid experiencing stigma and prejudice that might be found outside the leprosaria ${ }^{2,3}$. The survivors of this vertical health policy are now, for the most part, elderly and dependent.

Undiagnosed and untreated neuropathies are the most frequent cause of many disorders of the eyes, hands, and feet in persons with a history of leprosy. Even after achieving clinical cures, patients may present progressive disabilities that can lead to increased vulnerability and dependence ${ }^{4,5}$.

The majority of patients who contracted leprosy during the period of mandatory institutionalization and before the implementation of multidrug therapy (MDT) carry burdens from the disease. These physical alterations combined with the aging process and other associated ailments often lead to frailty, dependence and loss of personal autonomy². 
The objective of this study was to determine whether the physical impairments and disabilities linked to leprosy are associated with dependence among the elderly.

\section{METHODS}

\section{Study design}

This analytical cross-sectional study evaluated the association between physical impairments and disabilities caused by leprosy and dependence in the basic activities of daily living (BADL) and instrumental activities of daily living (IADL) in elderly affected by the disease.

\section{Study variables}

The outcome variables were BADL and IADL dependence, and the explanatory variables were the standard leprosy grades.

\section{Study population}

The sample was census-based and included elderly persons (60 years or older) with a history of leprosy registered in a former colony-hospital of the Minas Gerais State Hospital Foundation (Fundação Hospitalar do Estado de Minas Gerais - FHEMIG) in 2013. To eliminate the possibility of information bias, the analysis was limited to those individuals who did not present signs of cognitive deficits in the data records because this deficit is frequently associated with BADL and IADL dependence.

\section{Data collection}

The degree of physical impairment caused by leprosy was assessed in the patient records, according to the recommendations of the Brazilian Ministry of Health $(\mathrm{MoH})^{6,7}$. These impairments are defined using 'disability grades' by the $\mathrm{MoH}$ and the World Health Organization (WHO). We expressly chose to use the term 'physical impairment due to leprosy' as per the guidelines of the International Classification of Functioning, Disability and Health (ICF) given that the disability grading instrument used by the $\mathrm{MoH}$ describes alterations in specific body parts but not their functionality. This choice was based on the observation that a majority of authors currently refer to disability as a functional decline ${ }^{8}$.

The MoH data collection instrument to assess physical impairment from leprosy includes the following three grades: 0 indicates no problem with the eyes, hands and/or feet because of leprosy; 1 indicates reduced or lost sensation in the eyes, hands and/or feet; and 2 indicates visible damage to the eyes, hands and/or feet.

The Katz Index ${ }^{9}$ was used to evaluate BADL and to determine the level of self-care of older people. This index covers numerous activities, such as bathing, dressing, toilet use, movement, continence, and eating.

We utilized the Lawton Scale ${ }^{10}$ to determine IADL because it is an indicator of the capacity of elderly individuals to live alone in the community. This instrument covers activities related to household tasks and needs, such as telephone use, buying groceries, food preparation, cleaning, laundry, transportation, medication use, and financial control.

For this study, an Excel®, (Microsoft, Redmond, Washington, EUA) database was developed to register the patient evaluations performed in the outpatient sector of a former leprosy colony hospital. The database is updated annually by a multidisciplinary team (i.e., physiotherapists, occupational therapists, psychologists, dentists, speech therapists, and social workers) using the instruments described above. These tools jointly comprise the FHEMIG network protocol for the assessment and annual monitoring of the elderly ${ }^{11}$.

\section{Statistical analysis}

The collected data were organized in a new Excel spreadsheet specifically designed for this study. Subsequent statistical analyses were performed using the Statistical Package for the Social Sciences (SPSS) software, v.19.0, with level of significance fixed at 0.05 .

The physical impairment (disability) variable, broken down by standard grading, was analyzed dichotomously. We analyzed grades 0 and 1 as a single set as per a previous study ${ }^{12}$. The variables of dependence in BADL and IADL were also analyzed dichotomously because the objective of the study was to evaluate whether there an association between disability from leprosy and dependence, regardless of the extent.

\section{Ethical considerations}

This study was approved by the Research Ethics Committee of the FHEMIG under case number 296.757.

\section{RESULTS}

Data were collected from 186 elderly persons between the ages of 60 and 96 years with a history of leprosy. The average patient age was 75.2 years (standard deviation $-\mathrm{SD}=8.1$ years); further characterization of the study group is shown in Table 1.

The distribution of the elderly broken down by physical impairment because of leprosy (disability grading) and dependence levels for BADL (Katz Index) and IADL (Lawton Scale) are shown in Table 2. The majority of the subjects were classified as having grade 2 physical impairment because of leprosy, BADL independence, and partial dependence in IADL.

There is a statistically significant association between the impairment grade and IADL dependence. Among the IADLdependent individuals, $81.8 \%$ were classified as displaying grade 2 leprosy impairment, whereas $61.1 \%$ of the individuals who were independent in IADL showed grade 2 impairments (Table 3).

\section{DISCUSSION}

Frailty describes the condition of elderly persons with the highest risk of disability, institutionalization, hospitalization, and death ${ }^{13}$. In the national policy for older persons (Politica Nacional da Pessoa Idosa - PNPI) ${ }^{4}$, the at-risk criteria for frailty are as follows: resident in an institution for the long-term care 
TABLE 1 - Characteristics of elderly persons with a history of leprosy in a former colony-hospital of FHEMIG in 2013.

\begin{tabular}{|c|c|c|}
\hline Characteristics & Frequency & Percentage \\
\hline \multicolumn{3}{|l|}{ Age group } \\
\hline older than 75 years & 92 & 49.5 \\
\hline $60-75$ years & 94 & 50.5 \\
\hline \multicolumn{3}{|l|}{ Sex } \\
\hline female & 100 & 53.8 \\
\hline male & 86 & 46.2 \\
\hline \multicolumn{3}{|l|}{ Type of residence } \\
\hline ILTC & 45 & 24.2 \\
\hline individual household & 141 & 75.8 \\
\hline \multicolumn{3}{|l|}{ Formal education (years) } \\
\hline up to 4 & 173 & 93 \\
\hline 5 to 8 & 9 & 4.8 \\
\hline more than 8 & 4 & 2.2 \\
\hline \multicolumn{3}{|c|}{ Amputation of lower limbs } \\
\hline with amputation & 34 & 18.6 \\
\hline without amputation & 152 & 81.4 \\
\hline Total & 186 & 100.0 \\
\hline
\end{tabular}

FHEMIG: Fundação Hospitalar do Estado de Minas Gerais; ILTC: institution for long-term care of the elderly.
TABLE 2 - Distribution of elderly persons with a history of leprosy broken down by levels of physical impairment and dependence (BADL and IADL) in a former colony-hospital of FHEMIG in 2013.

\begin{tabular}{lcc}
\hline Variable & $\begin{array}{c}\text { Absolute } \\
\text { frequency }\end{array}$ & $\begin{array}{c}\text { Relative } \\
\text { frequency }\end{array}$ \\
\hline Physical impairment grade (because of leprosy) & 12 & 6.5 \\
grade 0 & 25 & 13.7 \\
grade 1 & 146 & 79.8 \\
grade 2 & $183^{*}$ & 100.0 \\
\hline Total & 155 & \\
\hline Katz index & 11 & 53.3 \\
independent & 20 & 10.8 \\
partially dependent & 186 & 100.0 \\
dependent & & \\
\hline Total & 19 & 10.2 \\
\hline Lawton scale & 147 & 79.0 \\
independent & 20 & 10.8 \\
partially dependent & 186 & 100.0 \\
dependent & & \\
\hline Total & 196 \\
\hline BADL: & & \\
\hline
\end{tabular}

BADL: basic activities of daily living; IADL: instrumental activities of daily living; FHEMIG: Fundação Hospitalar do Estado de Minas Gerais. *Information was unavailable for three individuals (1.6\%).

TABLE 3 - Univariate analysis of the association between the disability grade and the level of dependence in basic and instrumental activities of daily living among elderly persons with a history of leprosy in a former colony-hospital (FHEMIG).

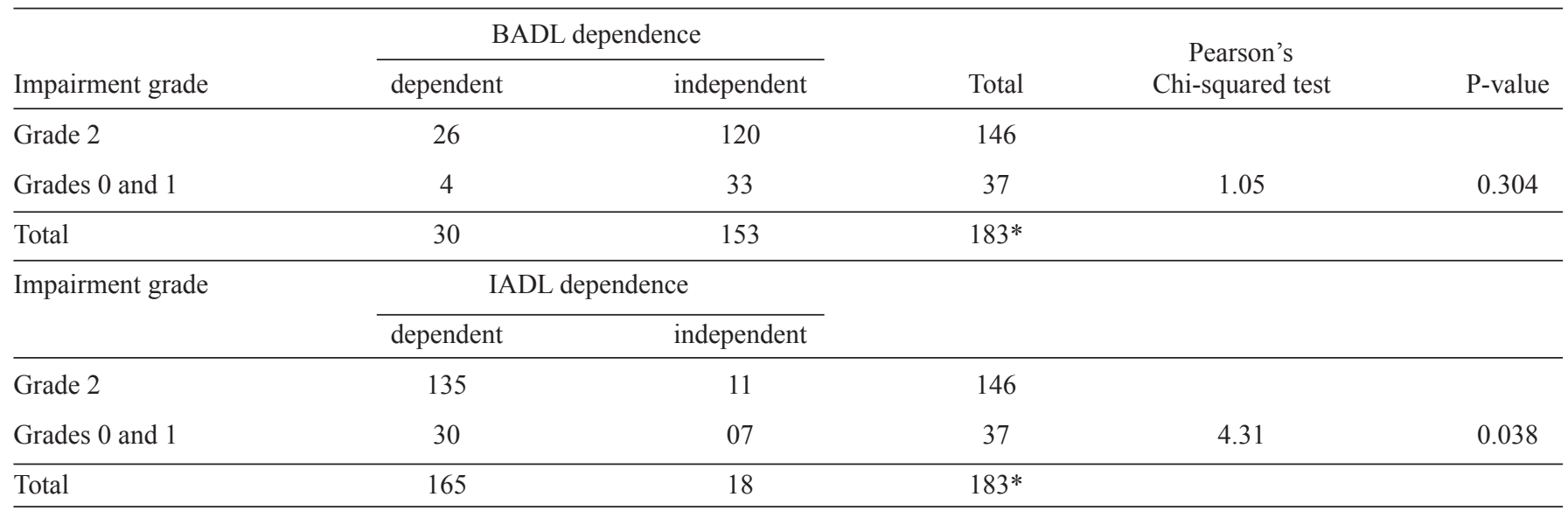

FHEMIG: Fundação Hospitalar do Estado de Minas Gerais; BADL: basic activities of daily living; IADL: instrumental activities of daily living. *No information for three (1.6\%) individuals. 
of the elderly (ILTC), bedridden, recently hospitalized, victim of domestic violence, amputee, and/or older than 75 years of age. Studies ${ }^{15,16}$ show that frail older persons frequently present comorbidities, advanced age, functional, and/or cognitive dependence, and decreased motor activity, as well as the use of multiple medications.

Considering these descriptions, we observed that a large part of the study population fits the standard risk factors for frailty. Approximately half of the individuals were older than 75 years of age, and approximately one-quarter lived in ILTCs. Of the elderly subjects evaluated in this study, $18.6 \%$ had a partial or complete leg amputation because of leprosy. We also observed that a majority of the individuals displayed dependence in activities of daily living, specifically IADL.

In relation to the sex of the study population, we found a greater prevalence of women with a history of leprosy than that observed in other studies ${ }^{17,18}$ in which there was no age discrimination. In the wider leprosy literature ${ }^{5,12,19}$, a greater prevalence is seen among men because of their more extensive social contact. It is important to consider the specificities of the group under evaluation because the literature ${ }^{20,21}$ describes the feminization associated with the aging process, due to the longer life expectancy of women. Considering these aspects and the results of the study, one perceives that much as in the general population, women affected by leprosy also have greater longevity.

The progression of impairments caused by leprosy can lead to extensive chronic ulcers and severe sequelae that leave the individual unable to perform daily life activities. Thirtyfour $(18.6 \%)$ of the older persons studied had lower limb amputations, which is a common treatment option in leprosy cases $^{22}$.

The percentage of grade $2(79.8 \%)$ impairment of the group under review was greater than the results from other international studies in which the prevalence of grade 3 impairment varied between $17 \%$ and $50 \%{ }^{23}$. Certain factors, such as the disease evolution before diagnosis and a lack of treatment with MDT and preventive follow-up, are related to a higher grade of physical impairment ${ }^{24,25}$. Nevertheless, it is important to consider the treatment history of each leprosy case. Because of their advanced ages, most of the individuals involved in this study showed signs of the disease in the period before the availability of MDT but during the time of compulsory isolation of leprosy patients. Consequently, the high percentage of grade 2 impairment reflects the absence or delay of treatment. Another aspect to be incorporated in data interpretation is the elevated frequency of physical impairment after being released from MDT treatment ${ }^{18}$. This situation occurs because in the absence of ongoing preventive care, lost sensation can evolve into a higher impairment grade. Previous studies ${ }^{26,27}$ have identified the need for rehabilitative measures in conjunction with pharmaceutical interventions to reduce sequelae and to help patients to maintain maximum functional capacity.

Regarding the completion of activities of daily living, the data show that the majority of individuals were independent in BADL, as observed in other studies that characterized the aged in general ${ }^{28-30}$. The high level of independence (83.3\%) of this group, most of whom had some degree of physical impairment, exceeded the average value of older Brazilians in other studies ${ }^{28-30}$ and that of patients from other Latin American and Caribbean countries ${ }^{31}$. This phenomenon might be related to greater resilience in individuals who quickly developed strategies to overcome impairment because of leprosy. More extensive patient follow-up performed by a multi-professional team and the exclusion of older persons with cognitive impairments also may have influenced the study results.

As for IADL, independence (10.2\%) was lower than other findings in the literature ${ }^{29,30}$. Higher prevalences of independence were observed in research elsewhere in Brazil (33.8\%), Chile (30.3\%), Argentina (27.6\%), and Cuba $(26.7 \%)^{31}$. Previous studies ${ }^{28-31}$ have shown that a low level of formal education, as observed among the study population, is associated with lower scores of IADL independence. This factor, linked with the sociocultural conditions of this group, may have contributed to the greater dependence in IADL observed in the study.

The association between the degree of physical impairment and the capability to perform BADL (Katz index) was not statistically significant $(\mathrm{p}=0.304)$. It was not possible to find similar studies that have examined functionality in older persons with a history of leprosy; therefore, no comparison of results could be conducted. Other studies that have evaluated leprosy disability grading and functional limitations because of leprosy using the Screening of Activity Limitation and Safety Awareness (SALSA) scale, regardless of age, did not show statistical significance $^{12,32}$. However, it has been demonstrated that leprosyrelated impairment interferes with the ability to complete daily life activities, even if it does not lead to a diagnosis of dependence. One presumes that functional limitation will increase along with the impairment grade. Nevertheless, it is difficult to classify this grade under the standard WHO disability scale given that patients with trophic lesions are included in the same grouping as those with wrist drop, thereby masking the results of impairment ${ }^{32}$.

The association between physical impairment grading and IADL was significant $(\mathrm{p}=0.038)$, although it was not possible to find data in the literature regarding the assessment of leprosy sequelae in the elderly in relation to IADL. Studies ${ }^{5,33,34}$ using the SALSA scale together with the Eye-Hand-Foot (EHF) score found a significant association between impairment and functional limitation. Therefore, it appears that there is a tendency for these patients to become less functional over time because of their impairments and comorbidities. Dependence constitutes an important risk factor for hospitalization, institutionalization, and death in an older population, and it often becomes more impactful than the diseases that lead to $\mathrm{it}^{35,36}$. The limitations in IADL contribute to social distancing and, consequently, isolationist tendencies given that IADL are related to the management of one's practical and social life $\mathrm{e}^{35}$. There is a hierarchy in the process of frailty. First, independence is lost in advanced activities of daily living, and this loss is followed by a loss of independence in IADL and, finally, BADL. Therefore, the study results indicate that the older people in this study are 
vulnerable to becoming dependent in BADL. The follow-up and rehabilitation of these patients are essential to prevent disabilities and preserve independence, autonomy and quality of life. In this sense, studies have shown that higher degrees of impairment are directly related to poor quality of life, even among individuals who are clinically cured ${ }^{37,38}$.

This study has certain limitations given that it uses secondary data on the impairment and dependence of older persons (with a history of leprosy) who resided in a former leprosy colony hospital and received care from a multidisciplinary team. These characteristics make any inference impossible for elderly persons affected by leprosy without similar multi-professional care and rehabilitation. Additional research on the functional capacity of older persons affected by leprosy is necessary to analyze how the impairments caused by this disease are associated with functional dependence, including other possible variables associated with this outcome. With more information, it should be possible to focus public policy and rehabilitation projects towards the promotion of an aging process with higher quality of life, preserved independence, and greater autonomy.

Physical impairment because of leprosy is associated with greater dependence in instrumental activities of daily living. This dependence necessitates increased social support and systematic follow-up by a multidisciplinary team. The results reported in this study highlight the importance of early diagnosis and treatment for leprosy to prevent physical impairment and dependence later in life.

\section{CONFLICT OF INTEREST}

The authors declare that there is no conflict of interest.

\section{REFERENCES}

1. Fundação Osvaldo Cruz. Negligência que faz mal à saúde. Rev Radis 2013; 124:13.

2. Savassi LCM, Bagutchi TR, Oliveira APS, Modena CM. A influência da internação compulsória em hospitais-colônia na qualidade de vida de cuidadores e pacientes com sequelas de hanseníase. Hansenol Int 2009; 34:21-31.

3. Ducatti I. A hanseníase no Brasil na era Vargas e a profilaxia do isolamento compulsório: estudos sobre o discurso científico legitimador. [Doctors Thesis]. São Paulo: Faculdade de Filosofia, Letras e Ciências Humanas, Universidade de São Paulo; 2009.

4. Sobrinho RAS, Mathias TAF, Lincoln P. Avaliação do grau de incapacidade em Hanseníase: uma estratégia para sensibilização e capacitação da equipe de enfermagem. Rev Lat Am Enfermagem 2007; 15:1125-1130.

5. Cunha ACSR. Censo de deficiências e incapacidades físicas por hanseníase e monitoramento pela escala salsa do plano de autocuidado para prevenção de incapacidades de pacientes atendidos em um centro de referencia nacional do Brasil. [Masters Dissertation]. Uberlândia: Universidade Federal de Uberlândia; 2012.

6. Ministério da Saúde. Secretaria de Políticas de Saúde. Departamento de Atenção Básica. Guia para o Controle da hanseníase. Brasília: Ministério da Saúde; 2002.

7. Ministério da saúde. Portaria $\mathrm{n}^{\circ} 3.125$, de 7 de outubro 2010. Brasília: Ministério da Saúde; 2010.

8. Alves LC, Leite LC, Machado CJ. Conceituando e Mensurando a incapacidade funcional da população idosa: uma revisão de literatura. Cien Saude Colet 2008; 13:1199-1207.
9. Katz S, Ford AB, Moskowitz RW, Jackson BA, Jaffe MW. Studies of illness in the aged. The Index of ADL: a standardized measure of biological and psychosocial function. JAMA 1963; 185:914-919.

10. Lawton MP, Brody P. Assessment of older people: Self maintaining and instrumental activities of daily living. Gerontologist 1969; 9:179-186.

11. Fundação Hospitalar do Estado de Minas Gerais [Internet]. Protocolo de Cuidados ao Idoso e Reabilitação [Cited March 2013]. Available at: http://www.fhemig.mg.gov.br/pt/protocolos-clinicos/.

12. Batista AMN. Avaliação da incapacidade e limitação de atividades em pacientes afetados pela hanseníase: uma análise do escore [Monografia de aprimoramento profissional em terapia ocupacional]. Bauru: Secretaria de Estado da Saúde. Coordenadoria de Controle de Doenças. Instituto Lauro de Souza Lima; 2010.

13. Lacas A, Rockwood K. Frailty in primary care: a revieew of its conceptualization and implications for practice. BMC Med 2012; 10:4.

14. Ministério da Saúde. Política Nacional de Saúde da Pessoa Idosa. Portaria MS/ $\mathrm{GM} \mathrm{n}^{\circ} 2.528$ de 19 de outubro de 2006. Brasília: Ministério da Saúde; 2006.

15. Teixeira INDO. Percepções de profissionais de saúde sobre duas definições de fragilidade no idoso. Cien Saude Colet 2008; 13:127-132.

16. Neri AL, Yassuda MS, Araújo LF, Eulálio MC, Cabral BE, Siqueira MEC, et al. Metodologia e perfil sociodemográfico, cognitivo e de fragilidade de idosos comunitários de sete cidades brasileiras: Estudo FIBRA. Cad Saude Publica 2013; 29:778-792.

17. Gomes CCD, Penna AGO, Aires MAP, Gonçalves HS. Perfil clínicoepidemiológico dos pacientes diagnosticados com hanseníase em um Centro de Referência na Região Nordeste do Brasil. An Bras Dermatol 2005; 80 (supl III):283-288.

18. Nardi SMT, Paschoal VD, Chiaravalloti-Neto F, Zanetta DMT. Deficiências após a alta medicamentosa da hanseníase: prevalência e distribuição espacial. Rev Saude Publica 2012; 46:969-977.

19. Almeida JRS, Alencar CH, Barbosa JC, Dias AA, Almeida MEL. Autopercepção de pessoas acometidas pela hanseníase sobre sua saúde bucal e necessidade de tratamento. Cien Saude Colet 2013; 18:817-826.

20. Del Duca GF, Silva SG, Thumé E, Santos IS, Hallal PC. Indicadores da institucionalização de idosos: estudo de casos e controles. Rev Saude Publica 2012; 46:147-153.

21. Veras R. Envelhecimento populacional contemporâneo: demanda, desafios e inovações. Rev Saude Publica 2009; 43:548-554.

22. Suguimoto N, Petrillo CR, Pebe ME. Hanseníase: amputação e próteses de membros inferiores. Hansenol Int 1977; 2:164-166.

23. Deepak S. Answering the rehabilitation needs of leprosy affected persons in integrated setting through primary health care services and community based rehabilitation. Indian J Lepr 2003; 75:127-142.

24. Alves CJM, Barreto JA, Fogagnolo L, Contin LA, Wolf NP. Avaliação do grau de incapacidade dos pacientes com diagnóstico de hanseníase em Serviço de Dermatologia do Estado de São Paulo. Rev Soc Bras Med Trop 2010; 43:460-461.

25. Ramos JMH, Souto FJD. Incapacidade pós-tratamento em pacientes hansenianos em Várzea Grande, Estado de Mato Grosso. Rev Soc Bras Med Trop 2010; 43:293-297.

26. Carvalho GA, Alvarez RRA. Avaliação de incapacidades físicas neuromúsculo-esqueléticas em pacientes com hanseníase. Hansenol Int 2000; 25:39-48

27. Gonçalves SD, Ssmpaio RF, Antunes CMF. Fatores preditivos de incapacidades em pacientes com hanseníase. Rev Saude Publica 2009; 43:267-274.

28. Alencar MA, Bruck NNS, Pereira BC, Câmara TMM, Almeida RDS. Perfil dos idosos residentes em uma instituição de longa permanência. Rev Bras Geriatr Geronto 2012; 15:785-796.

29. Duca GFD, Silva MCD, Hallal PC. Incapacidade funcional para atividades básicas e instrumentais da vida diária em idosos. Rev Saude Publica 2009; 43:796-805.

30. Pereira GN, Bastos GAN, Duca GFD, Bós AJG. Indicadores demográficos e socioeconômicos associados à incapacidade funcional em idosos. Cad Saude Publica 2012; 28:2035-2042. 
31. Reyes-Ortiz CA, Ostir GV, Pelaez M, Ottenbacher KJ. Cross-national comparison of disability in Latin American and Caribbean persons aged 75 and older. Arch Gerontol Geriatr 2006; 42:21-33.

32. Rafael AC. Pacientes em tratamento e pós alta em hanseníase: estudo comparativo entre os graus de incapacidade preconizados pelo Ministério da Saúde correlacionando-os com as escalas SALSA e Participação Social [Masters Dissertation]. Brasília: Universidade de Brasília; 2009.

33. Ikehara E, Nardi SMT, Ferrigno SV, Pedro HSP, Paschoal VD. Escala Salsa e grau de Incapacidades da Organização Mundial de Saúde: avaliação da limitação de atividades e deficiência na hanseníase. Acta Fisiatr 2010; 17:169-174.

34. Barbosa JC. Pós-alta em hanseníase no Ceará: olhares sobre políticas, rede de atenção à saúde, limitação funcional, de atividades e participação social das pessoas atingidas [Doctors Thesis]. São Paulo: Univesidade de São Paulo; 2009.
35. Brito TRP, Pavarini SCI. The relationship between social support and functional capacity in elderly persons with cognitive alterations. Rev Lat Am Enfermagem 2012; 20:677-684.

36. Saliba D, Elliott M, Rubenstein LZ, Solomon DH, Young RT, Kamberg CJ, et al. The vulnerable elders survey: a tool for identifying vulnerable older people in the community. J Am Geriatr Soc 2001; 49:1691-1699.

37. Proto RS, Machado Filho CDS, Rehder JRCL, Paixão MP, Angelucci, RI. Qualidade de vida em hanseníase: análise comparativa entre pacientes da região Amazônica com pacientes da região do $\mathrm{ABC}$, São Paulo, Brasil. An Bras Dermatol 2010; 85:939-941.

38. Lustosa AA, Nogueira LT, Pedrosa JIS, Teles JBM, Campelo V. The impact of leprosy on health-related quality of life. Rev Soc Bras Med Trop 2011; 44:621-626. 